\title{
【特 集：最終処分場技術の変遷と今後の展望】
}

\section{最終処分場の技術的変遷と今後の動向}

\author{
樋口壯太郎
}

【要 旨】わが国は焼却や破砕により都市廃棄物の減容化, 無害化を行った後, 残渣を埋立処分するこ とを廃棄物処理の基本としている。このため埋立処分される廃棄物は焼却残渣が $75 \%$ を超えている。 このような背景下, 焼却残渣の埋立に伴い生ずる課題として無機塩類対策, 副生塩資源化, 有機キレー 卜剂による浸出水処理阻害，早期安定化等をあげ，これらの課題解決の方法について検討した。

キーワード：埋立ごみ質, 無機塩類, 副生塩, キレート剤, 硝化阻害

\section{1.は じめに}

わが国の廃棄物管理の基本原則は, 廃棄物の発生抑制, 資源化に努め, 排出された廃衰物を焼却等中間処理によ り減容化, 無害化したのち, 残椬を埋立処分することに ある。これは国土が狭く最終処分場用地の確保が極めて 困難であるという国土事情に起因している。このため一 般廃棄物については世界に先駆けて焼却炉を導入し，世 界屈指の焼却大国となった。一方で, 最終処分場技術に ついては，焼却炉普及率が 50\% 以下であった 1960 年代 に開発された，埋立地をバイオリアクターとして活用す る「準好気性埋立構造」が中心となり，焼却炉普及後は 焼却残椬を中心とした埋立技術や「被覆型処分場（ク ローズドシステム処分場)」等が開発され普及してきた。 その他, 海面処分場 (水面を残したままの廃棄物の埋 立) の存在，あるいは埋立終了後のキャッピング規定が ないことなど，国際的にも例をみない独自の技術を有し ている。一方, 焼却のさらなる高度化により埋立ごみ質 も変動し, 今日において廃棄物最終処分場はさまざまな 課題が顕在化してきた。本報では, 最終処分技術のこれ までの変遷と埋立ごみ質の変遷を整理したうえで, これ からの最終処分場に求められる課題や対策について考察 した。

原稿受付 2014.12.21

* 福岡大学大学院 工学研究科

連絡先： ₹ 808-0135 北九州市若松区ひびきの 2-1

E-mail : higuchis@rj8.so-net.ne.jp

\section{2. 埋立ごみ質と最終処分技術の変遷}

\section{1 一般廃棄物排出量と処理処分の変遷}

図 1 に 5 年ごとの一般廃棄物排出量と処理処分の内訳 を示した ${ }^{1,2)}$ 。これより排出量は 2000 年まで増加し, 年 間約 5,000 万 ton をピークに, 以降減少傾向に転じてい ることがわかる。一方, 処理処分は1965 年にはすでに 約 40\% が焼却されており，1990 年以降は約 $80 \%$ に達し ている。一般廃棄物排出量の約 $80 \%$ は可燃ごみである ことから焼却率はほほ $100 \%$ に達したと予想される。焼 却されたごみの約 $10 \%$ が焼却残椬として埋立処分され る。また直接埋立の比率は年々減少し, 1965 年 47.6\%, 1990 年 $19.9 \%, 2000$ 年 5.9\%, 2010 年には $1.5 \%$ に減少 している。これは自治体がリサイクルセンターの建設 を推進し, 資源化処理の促進と処分量削減に努めた結 果といえる。これより1990 年に可燃ごみ焼却率がほぼ 100\%に達したと仮定すると，1990 年以前の直接埋立は 可燃ごみ, 不燃ごみおよび粗大ごみで, 1990 年以降は 可燃ごみの直接埋立は実質なくなったと推察される。ま た図 1 には法律や基準改正の時期，社会背景等を示した。 ここで最終処分場に深く関わるできごととして 1977 年 の「廃棄物焼却炉に係る塩化水素及び窒素酸化物の排出 規制について」と 1979 年の「廃棄物焼却炉に係る窒素 酸化物の排出規制について」があげられる。これにより 飛灰の処分場への搬入割合が増加しはじめ, これ以降, 徐々に埋立地における無機塩類問題が顕在化しはじめて, 埋立ごみに占める焼却残椬の増加とともに大きな問題に なった。 


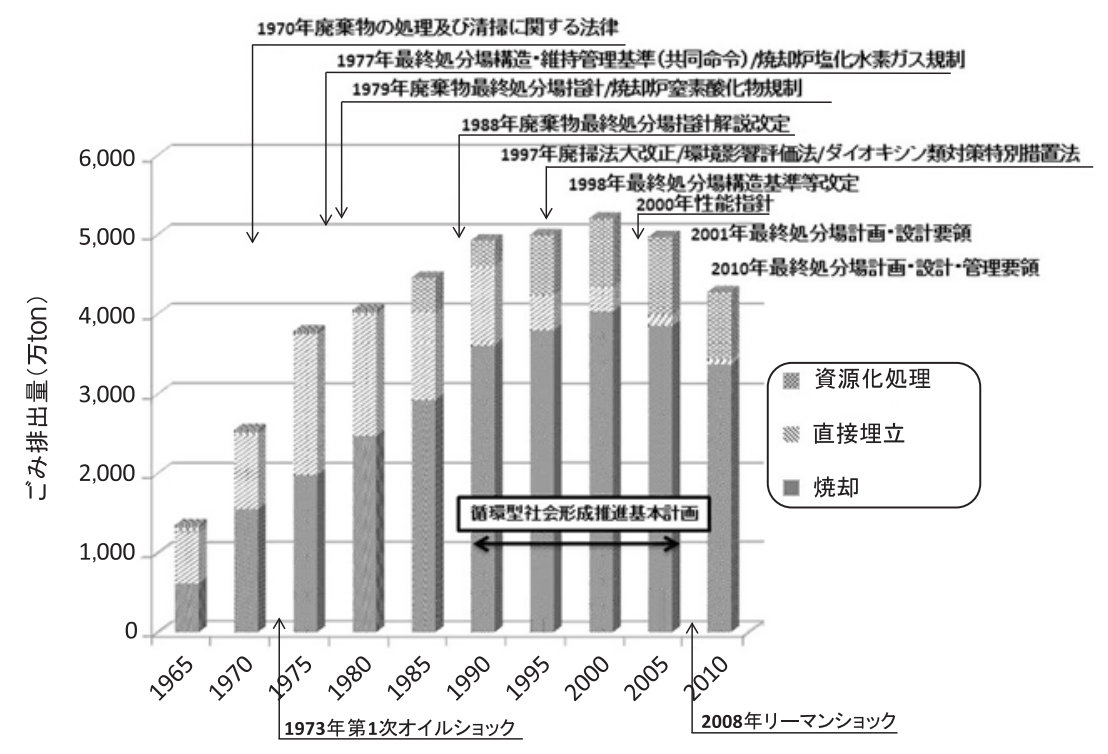

高度経済成長至ブル経済

廃棄物年鑑1)，一般廃棄物の排出及び処理状況等（平成 24 年度）について ${ }^{2)}$ から抜粋, 追記

図 1 一般廃棄物処理処分の変遷
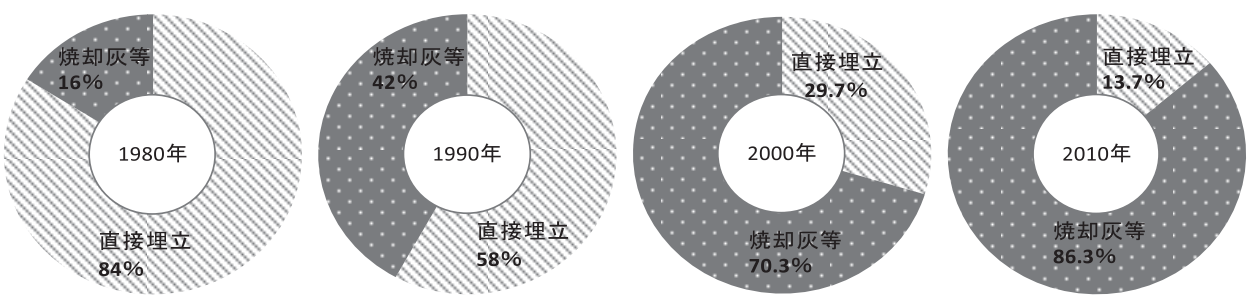

廃棄物年鑑1)，一般廃棄物の排出及び処理状況等（平成 24 年度）について ${ }^{3}$ を参考に作図

図 2 一般廃棄物種類別埋立比率の変遷

\section{2 埋立物の変遷}

図 2 に 1980 年から 2010 年の埋立ごみ量の種類別比率 を示した ${ }^{1,3)}$ 。ただしこの図の焼却灰等には主灰，飛灰， 資源化施設等からの中間処理残椬を含む。1990 年の焼 却灰等は全埋立量の $42 \%, 2000$ 年には 70.3\%, 2010 年 には $86.3 \%$ に増加している。さらに埋立ごみの種類を 分類推定するために焼却灰等を焼却残椬と中間処理残椬 に分け, さらに焼却残椬中の主灰と飛灰の比率を重量比 $3: 7$ で分けた。その結果を図 3 に示した ${ }^{2,3)}$ 。図 3 より 2012 年の埋立ごみは焼却残椬 74.4\%（焼却灰 $52.1 \%$, 飛 灰 $22.3 \%$ ）, 中間処理残椬 $14.4 \%$ (破砕不燃ごみ), 直接 埋立ごみ $12.1 \%$ (不燃ごみ) と推察される。

\section{3 埋立ごみ質と最終処分技術の变遷}

\section{3 .11960 年代 (嫌気的埋立)}

わが国の高度経済成長が始まり都市部のごみ量が急増

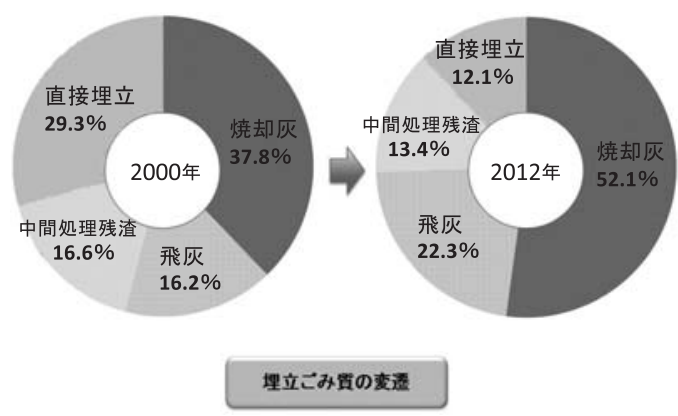

一般廃寨物の排出及び処理状況等について 2.3$)$ を参考に作図 図 3 一般廃棄物種類別埋立比率（2000, 2012 年）

したが，多くの自治体がまだ全量埋立を行っており，大 都市では最終処分場不足が深刻となって，海面に処分場 を求めたり焼却炉が導入されたりしはじめた。埋立技術 
は確立されておらず, オープンダンピングに近い状況で, 悪臭, 鼠族 · 昆虫 · カラス問題, 高濃度有機物浸出水に よる水質污濁等が問題となった。埋立ごみ質は約 $60 \%$ が可燃ごみ, 約 $30 \%$ が不燃ごみ等の直接埋立で, 約 $10 \%$ が焼却残椬で占められていた。浸出水処理施設を 有していない処分場が大半であった。

\subsubsection{0 年代 (準好気性埋立構造)}

廃竦物の処理及び清掃に関する法律 (以下, 廃棄物処 理法）が制定され，最終処分場の技術基準として構造基 準, 維持管理基準が制定された。これにより覆土や浸出 水処理施設の設置が義務づけされた。一般廃棄物最終処 分場には原則 $25 \%$ の補助金が交付されるようになり, 「廃棄物最終処分場指針解説」が発行された。可燃ごみ の焼却率は $65 \%$ 程度で浸出水やガス濃度は低減化傾向 にあるものの水質污濁や悪臭問題は依然として大きな社 会問題であった。浸出水処理の対象水質項目は BOD (生 物化学的酸素要求量), COD (化学的酸素要求量), $\mathrm{T}-\mathrm{N}$ (総窒素) であり，窒素による農業被害（成長過多による 青立ち現象）対策が水質管理上の課題となった。このよ うな中で準好気性埋立構造は, 埋立ごみや浸出水の早期 安定化技術としてわが国の埋立技術の中心としての位置 づけが確立された。浸出水処理技術はまだ手探りの状況 で, 散水ろ床法, アンモニアストリッピング法, ラグー ン法等の生物処理や石灰凝集沈殿法等で対処されていた。 一方, 焼却施設においては 1977 年に塩化水素ガス規制, 1979 年に窒素酸化物規制が定められた。

\subsubsection{0 年代（遮水工, カルシウム除去）}

燒却炉の普及が著しく, 可燃ごみ焼却率は $80 \%$ に達 した。それに伴い浸出水中の BOD, COD, T-N 濃度は急 激に低減化し, 反面, 浸出水中のカルシウムイオンによ る機器スケーリングや塩素イオンによる水処理障害ある いは農業被害等, 高濃度無機塩類問題が顕在化してきた。 最終処分場には遮水工が敷設されはじめ, 塩類対策技術 としてライムソーダ法によるカルシウム除去技術等が開 発された。このような背景下「廃棄物最終処分場指針解 説」が改訂された。浸出水処理技術はカルシウム除去十 接触ばっ気，回転円板法等による生物処理（生物学的硝 化脱窒法) +弱酸性凝集沈殿法十万過十活性炭吸着法が 標準的浸出水処理法となった。

\subsubsection{0 年代 (二重遮水, 脱塩処理)}

可燃ごみの焼却率はほほ $100 \%$ となり, 一般廃棄物最 終処分場の埋立ごみ質は現在の水準に近くなり，飛灰の 溶融処理が実施されはじめた。1999 年にはダイオキシ ン類対策特別措置法が定められ, 最終処分場にも即日覆 土等による飛散防止, 浸出水の SS (浮遊物質) 管理が 求められた。また遮水工破損による地下水污染懸念等が
社会問題となり，1998 年に構造基準・維持管理基準の 基準強化が行われ，二重遮水工が義務づけられた。これ に伴い漏水検知システムの開発も行われるようになった。 さらに廃止基準が定められた。このような背景下, 被覆 型最終処分場（クローズドシステム処分場）第 1 号施設 が建設された。

2.3.5 2000 年代以降〜現在（ED 法, RO 法による脱塩, 副生塩問題, 促進酸化によるダイオキシン類分 解技術)

2000 年に「廃棄物最終処分場指針解説」に替わり 「最終処分場整備に係る計画, 設計要領」が発行された。 第一次循環型社会形成推進基本計画（2003 年）により 定められた最終処分量削減目標から, リサイクルセン ターの建設等により資源化が進み, 2010 年には最終処 分量は 1990 年比で $25 \%$ まで削減され, 最終処分場規模 が小規模化するようになって, 被覆型最終処分場の建設 事例が急増した。さらに浸出水処理へ脱塩処理設備を導 入するところが増加し, 副生塩問題も顕在化してきた。 浸出水処理対象項目は低濃度の BOD, COD, T-N, SS, カルシウムイオン, 塩素イオンが中心となった。また 1998 年に廃止基準が制定されたことから維持管理の重 要性が高まり, 2010 年には「最終処分場整備に係る計 画, 設計要領」が「最終処分場整備に係る計画・設計 · 管理要領」に改訂された。前述したように，わが国の埋 立システムは諸外国と比べて独自の技術を有している。 今後, さらに焼却等上流側システムと連携した埋立シス テムが求められる。

\section{3. 最終処分技術の課題と対策}

わが国の最終処分場は高度経済成長期における廃㶳物 の急激な増加や気候, 地形等の国土事情から, 欧米とは 異なる方式で独自に発展してきた。それは (1)焼却等中 間処理導入による減容化, 無害化, および安定化を行い, 「残椬を埋立処分」すること。(2)自然の有機物浄化機能 とその分解メカニズムを最大限に利用する「準好気性埋 立」を基本技術とすること。(3)一部の地域では海面に 最終処分場を求めたこと。(4)降水量が多いことから污 濁物の「降水による洗い出し」の後, 浸出水処理施設に よる処理により安定化させること。および, これに伴い (5)埋立終了後のキャッピング規定がないことなどがあ げられる。現在の埋立技術の技術的課題と対応策につい て以下に示す。

\section{1 高濃度無機塩類問題}

最終処分場に埋立処分される焼却残椬の比率が上昇し, 
焼却炉の排ガス処理が高度化されることにより焼却残渣 中の飛灰の比率が増え，浸出水中の高濃度無機塩類濃度 が上昇している。筆者らの試算によると 2010 年度の焼 却残渣中に含まれる塩素量は約 13.6 万 ton（主灰 3.0 万 ton, 飛灰 10.6 万 ton）である ${ }^{4)}$ 。過去の塩素埋立量と比 較すると 1994 年の年間 4.3 万 ton $^{5)}$ に比べ 3.2 倍であり, 埋立処分量が減少しているにも関わらず，増加している。 この要因として塩化水素ガス処理の高度化があげられる。 1994 年の自治体の塩化水素ガス処理性能は平均 150 ppm に対し, 2010 年においては乾式 $50 \mathrm{ppm}$, 湿式 10 $\mathrm{ppm}$ となっている ${ }^{4)}$ 。これらのことから浸出水中の塩素 イオン濃度は上昇傾向にあり, 浸出水管理に塩類対策を 考慮する必要性が高くなってきている。塩類対策として 浸出水の脱塩処理を行うと, 濃縮塩が生成する。この処 理や保管, あるいは再利用方法の問題は未だ完全に解決 されていない課題である。一方, 乾式排ガス処理に用い られる石灰等については 1990 年代には塩化水素ガスの 反応当量比 3.0 程度を吹き込んで扔り, 未反応石灰等に よる浸出水中のカルシウムイオン濃度は数千 $\mathrm{mg} / \mathrm{L} に$ 上昇し, カルシウムスケールによる障害が問題となった。 現在は高反応型薬剤の開発により当量比 1.2 程度に抑え られているが，前述したように排ガス処理性能の向上に より, 薬剂使用量が増加しているため, カルシウムス ケール等の問題は解決していないと推察している。

\section{2 副生塩対策}

一般廃棄物の処理処分工程から環境中に排出される塩 類は年間約 21.1 万 ton といわれている。このうち約 13.6 万 ton が最終処分場へ搬入されている ${ }^{4)}$ 。このため 浸出水中の塩類濃度が上昇し, 浸出水処理工程中に脱塩 処理装置を組み込む自治体が増加している。しかし脱塩 処理に伴い生成する濃縮塩（以下, 副生塩と称する) の 問題がある。筆者らが浸出水処理に脱塩処理プロセスを 組み达んだ 27 施設を対象に実施した副生塩に関するア ンケート調査結果によれば, 多くの施設で保管または産 業廃棄物処分 (以下, 産廃処分) されており, 長期保管 できない場合は産廃処分をしているところが多かった。 処分費用は 15,000 63,000 円/ton であった ${ }^{4)}$ 。この問題 を解決するためには副生塩の有効利用が望まれる。しか しソーダ工業を中心とする塩使用企業は現在, 輸入塩コ ストが安価であることや副生塩の品質から副生塩を使用 することに消極的である。現時点で考えられる副生塩使 用方法としてソーダ工業利用, 道路凍結防止剤, アルミ 精錬フラックス剂, 次亜塩素酸ナトリウムの生成等が考 えられる。ここでは副生塩から次亜塩素酸ナトリウムを 生成させ, 消毒剂に利用する事例研究について記載する。
表 1 副生塩の組成

\begin{tabular}{|c|c|c|c|c|c|c|}
\hline \multirow{2}{*}{ 項 目 } & \multirow{2}{*}{ 単位 } & \multicolumn{4}{|c|}{ 副生塩 } & \multirow{2}{*}{$\begin{array}{l}\text { 精製塩 } \\
\text { (市販品) }\end{array}$} \\
\hline & & A-1 & A-2 & A-3 & B-1 & \\
\hline $\mathrm{Na}$ & $\%$ & 22 & 27 & 22 & 37 & 39 \\
\hline $\mathrm{Cl}$ & $\%$ & 52 & 47 & 54 & 52 & 60 \\
\hline $\mathrm{K}$ & $\%$ & 22 & 11 & 13 & 0.30 & 0.024 \\
\hline $\mathrm{Ca}$ & $\%$ & 0.017 & $<0.01$ & 5.0 & $<0.01$ & 0.033 \\
\hline $\mathrm{Mg}$ & $\%$ & 0.013 & $<0.01$ & $<0.01$ & 0.01 & 0.018 \\
\hline $\mathrm{SO}_{4}$ & $\%$ & 1.9 & 4.4 & 0.66 & 5.0 & 0.088 \\
\hline $\mathrm{CO}_{3}$ & $\%$ & 0.18 & 7.0 & 1.3 & 3.7 & 0.034 \\
\hline TOC & $\%$ & $<0.01$ & 0.033 & 0.23 & 0.036 & 0.014 \\
\hline $\mathrm{Br}$ & $\mathrm{mg} / \mathrm{kg}$ & 2200 & 1400 & 1700 & 2800 & 35 \\
\hline $\mathrm{SiO}_{2}$ & $\mathrm{mg} / \mathrm{kg}$ & $<10$ & 100 & 410 & 86 & $<10$ \\
\hline $\mathrm{NaCl}^{* 1}$ & $\%$ & 53 & 56 & 53 & 84 & 99 \\
\hline $\mathrm{KCl}^{* 2}$ & $\%$ & 43 & 20 & 25 & 0.57 & 0.05 \\
\hline $\mathrm{NaCl}+\mathrm{KCl}$ & $\%$ & 96 & 76 & 78 & 85 & 99 \\
\hline
\end{tabular}

※1）まず， $\mathrm{SO}_{4}$ は全量が $\mathrm{Na}_{2} \mathrm{SO}_{4}$ に， $\mathrm{CO}_{3}$ は全量が $\mathrm{Na}_{2} \mathrm{CO}_{3}$ また は $\mathrm{NaHCO}_{3}$ になっているものと仮定し，それにより使わ れない残りの $\mathrm{Na}$ が $\mathrm{NaCl}$ になっているものとして計算

※ 2） K の全量が $\mathrm{KCl}$ になっているとして計算

表 1 に発生源別副生塩組成を示した。A-1, A-2 は浸出 水処理施設より発生したもので, カルシウム(以下, Ca）除去プロセスが組み込まれてる。A-3 も浸出水処 理施設よりの副生塩であるが，Ca 除去は行われていな い。 B-1 は焼却施設の二段バグフィルタ後段でナトリウ ム系脱塩剤を吹き込み, 回収した副生塩である。表 1 よ り浸出水由来の副生塩には, ナトリウム (以下, $\mathrm{Na}$ )イ オンの他に, カリウム (以下，K) イオンが含まれている。 これらの分離は経済的な理由から困難であり，Kイオ ンを含むままで副生塩を生成させる。このため生成する のは次亜塩素酸ソーダ $(\mathrm{NaClO})$ のみならず, 次亜塩素 酸カリウム $(\mathrm{KClO})$ が含まれているため, これをエコ 次亜塩素酸ソーダと呼んでいる（以下，エコ次巠と称す る)。

図 4 に無隔膜電気分解法の実験フローを示した6)。電 極面積が $50 \mathrm{~cm}^{2}\left(0.5 \mathrm{dm}^{2}\right)$ で, 電極は陽極に Ti+特殊 コーティング，陰極はステンレスを用いている。実験条 件として, 塩水供給量約 $5 \mathrm{~L} / \mathrm{h}$, 塩水濃度として 30〜

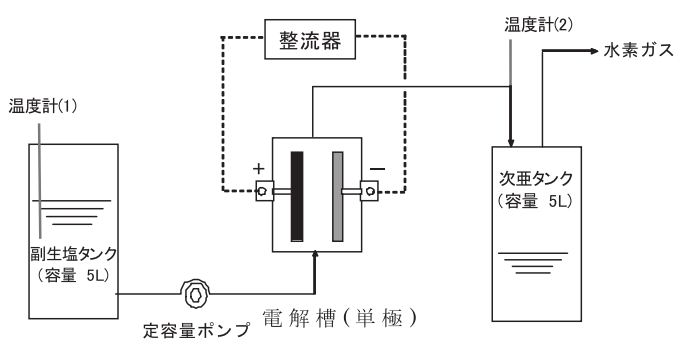

図 4 電解実験フロー6) 


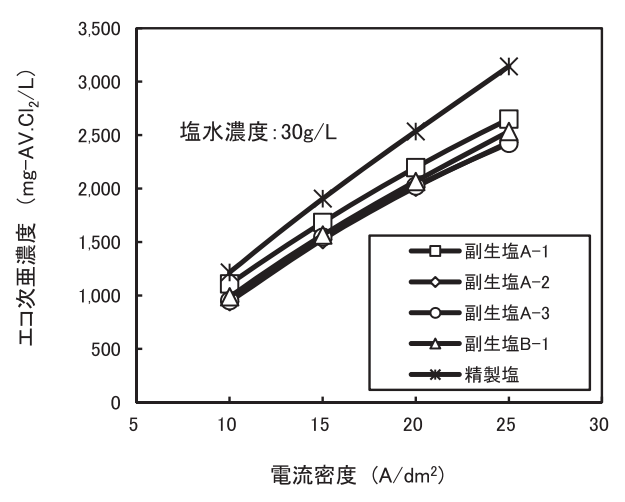

図 5 電流密度とエコ次亜濃度 ${ }^{6)}$

$200 \mathrm{~g} / \mathrm{L}$ ( $\mathrm{NaCl}$ 換算), 電解電圧 3.5 4.2 V, 電解電流 $5.0 \sim 12.5 \mathrm{~A}$, 電流密度 $10 \sim 25 \mathrm{~A} / \mathrm{dm}^{2}$ で, 実験温度は常 温である。実験により, 副生塩においては, 塩水濃度が $30 \mathrm{~g} / \mathrm{L}$, 電流密度 $15 \mathrm{~A} / \mathrm{dm}^{2}$ のときに最も電流効率が高 いことがわかっている4)。この条件において図 5 より発 生エコ次亜濃度は約 $1,500 \mathrm{mg}-\mathrm{AV} . \mathrm{Cl}_{2} / \mathrm{L}\left(\mathrm{AV} . \mathrm{Cl}_{2}\right.$ : 有効 塩素值 $\fallingdotseq 100 \% \mathrm{NaClO}$ を示す) である ${ }^{6)}$ 。

これらの研究結果等 ${ }^{4)}$ より無隔膜電気分解法は塩水の $\mathrm{Ca}$ イオン濃度が $100 \mathrm{mg} / \mathrm{L}$ 以下であれば有効塩素濃度 1,500 5,000 mg/L のエコ次亜が得られ, 消毒剤として 有効利用が可能であり, 実用化可能の段階にある。ただ し, 下水道終末処理施設等エコ次亜の需要側の確保が必 要であり, 経済的成立条件は副生塩 0.5 ton/日以上（人 口 10 万人以上）である ${ }^{4)}$

\section{3 浸出水中の残存キレート問題}

図 3 に示したとおり 2010 年の埋立比率に占める飛灰 は $22 \%$ となっている。飛灰は特別管理一般廃棄物に指 定されており, 廃棄物処理法により 4 つの方法（溶融固 化, セメント固化, 薬剂処理, 酸その他の溶媒による安 定化）のいずれかによる処理が義務づけられている。こ れらの処理方式の中ではキレート剂による処理が主流と なっており, 筆者らが実施したアンケート調査では
$78 \%$ の焼却施設で使用され，そのうち $98 \%$ が有機系キ レート剂を使用している7)。このような中でキレート剂 に起因すると考えられる硝化阻害や COD 除去率の低下 等浸出水処理への影響, ひいては安定化遅延の影響が顕 在化しはじめている。表 2 に 市の飛灰および市販の $\mathrm{B}$ 社のキレート剂の組成分析を行った結果を示した。表 2 の飛灰の組成分析結果から, COD Cr $の$ 総量は $2.7 \mathrm{wt} \%$ を示し, 約 $86 \%$ が $\mathrm{COD}_{\mathrm{Mn}}$ で検出されない難分解性 COD (以降, $\mathrm{COD}_{\mathrm{Cr}}-\mathrm{COD}_{\mathrm{Mn}}$ を「難分解性 $\mathrm{COD}$ と称する) となっている。有機系キレート剤の組成はジチオカルバ ミン酸系に含まれる $\mathrm{COD}_{\mathrm{Cr}}$ 成分の総量で $39.0 \mathrm{wt} \%$ を占 め, 52.3\% が難分解性 COD であった。窒素成分は 2.4 $\mathrm{wt} \%$ であった。ピペラジン系では $\mathrm{COD}_{\mathrm{Cr}}$ の総量で 30.9 $\mathrm{wt} \%$ を占め, $71.1 \mathrm{wt} \%$ が難分解性 COD となり, 窒素 成分は $2.8 \mathrm{wt} \%$ であった。無機系キレート剂では, $\mathrm{COD}_{\mathrm{Cr}}$ の総量で $8.9 \times 10^{-4} \mathrm{wt} \%$ と極めて低い值を示し, 窒素成分は検出されなかった。有機系キレート剂は硝化 阻害物質であるチオ尿素と類似した化学結合構造をもつ ことから, 硝化阻害作用があることも考えられる（図 6)。仮に硝化阻害作用が認められる場合, 浸出水処理の 管理としてBODを指標としている施設等については, 硝化阻害によって硝化による酸素消費量（N-BOD）が 抑制されるため, 見かけの BOD 值は過小評価されるこ ととなり, 特にアンモニア性窒素の濃度が高いほど影響

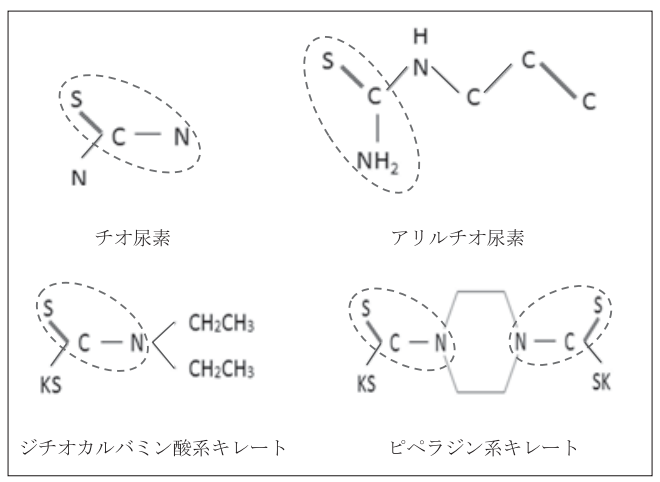

図 6 チオ尿素と工業用キレートの化学構造例 ${ }^{16)}$

表 2 飛灰およびキレート剂の組成

\begin{tabular}{|l|c|c|c|c|c|c|c|c|c|c|c|}
\hline \multicolumn{1}{|c|}{ 試料名称 } & 単位 & 比重 & $\mathrm{pH}$ & $\mathrm{COD}$ & $\mathrm{COD}$ & $\mathrm{Cl}^{-}$ & $\mathrm{T}-\mathrm{N}$ & $\mathrm{T}-\mathrm{P}$ & $\begin{array}{c}\text { チオ尿素様 } \\
\text { 物質 }\end{array}$ & $\mathrm{T}-\mathrm{S}$ & $\mathrm{Pb}$ \\
\hline 飛灰 & $\mathrm{mg} / \mathrm{kg}$ & - & 12.2 & 3,700 & 27,000 & 220,000 & 280 & 3,100 & - & 7,700 & 1,500 \\
\hline ジチオカルバミン酸系 & $\mathrm{mg} / \mathrm{L}$ & 1.18 & $>14$ & 220,000 & 460,000 & 130,000 & 28,000 & 12 & 10,000 & 110,000 & - \\
\hline & $\mathrm{mg} / \mathrm{kg}$ & - & - & 186,441 & 389,831 & 110,169 & 23,729 & 10 & 8,475 & 93,220 & - \\
\hline ピペラジン系 & $\mathrm{mg} / \mathrm{L}$ & 1.23 & 13.6 & 110,000 & 380,000 & 110,000 & 35,000 & $<10$ & 5,300 & 190,000 & - \\
\hline & $\mathrm{mg} / \mathrm{kg}$ & - & - & 89,431 & 308,943 & 89,431 & 28,455 & $<8$ & 4,309 & 154,472 & - \\
\hline 無機リン系 & $\mathrm{mg} / \mathrm{L}$ & 1.53 & $<1$ & 3.2 & 14 & $<40$ & $<40$ & 410,000 & $<2.5$ & $<320$ & - \\
\hline & $\mathrm{mg} / \mathrm{kg}$ & - & - & 2.0 & 8.9 & $<25$ & $<25$ & 261,146 & $<2$ & $<204$ & - \\
\hline
\end{tabular}


は大きいものと考えられる。 $\mathrm{A}$ 社の有機系キレート剂 には $0.5 \sim 1.0 \%$ のオ尿素様物質が含まれていた（間接 吸光光度法により 分析 $\left.{ }^{8,9)}\right)$ 。一方, 無機キレートのリン 系キレート剤については塩化物イオンや COD は少なく, チオ尿素様物質については検出されなかったため浸出水 への硝化阻害や COD への影響はないと推察される。こ れらのことから有機系キレート剂にはチオ尿素様物質を 含み, 残存キレートによる硝化阻害や COD 除去率低下 を起こす可能性が考えられる。硝化阻害としてアンモニ アモノキシゲナーゼを $70 \%$ 以上阻害する最低濃度はチ オ尿素で $37.4 \mu \mathrm{mol}$ (約 $3 \mathrm{mg} / \mathrm{L})$, ジエチルジチオカル バミン酸ナトリウム (DDTC-Na) で $10 \mu \mathrm{mol}$ (約 $2 \mathrm{mg}$ )

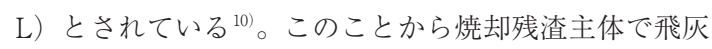
処理に薬剂処理を行い, 有機系キレート剂を使用してい る最終処分場においては浸出水管理上, 残存キレート中 の難分解性有機物である COD の問題とチ才尿素様物質 による硝化阻害対策を強化する必要性がある。飛死処理 に溶融を採用する場合においても溶融飛灰の安定化処理 を行い，埋立処分する場合には同様な配慮が必要である。

現時点において有機系キレートを用いた飛灰が搬入さ れる処分場においては, 浸出水の内部貯留の回避による 残存キレートの溶出抑制や残存キレートの促進酸化等に よる酸化分解が有効な対策である ${ }^{7,11)}$ 。抜本的対策とし ては焼却施設においてキレート剂を無機系に変えること が最も確実である。

\section{4 高濃度無機塩類下における準好気性埋立構造}

わが国の埋立技術のベースとなっている「準好気性埋 立」は, 自然のサイクルとその分解メカニズムを利用し て，埋立地を一種のバイオリアクターとして用い有機物 を早期に分解する埋立技術である。またバイオリアク 夕ー機能は, 海外のように全量埋立を行っている有機物 負荷の大きい処分場から, 不燃物や焼却残椬のように有 機物負荷の小さい処分場まで, 幅広い適用性を有してい る。しかし現在の焼却残椬主体の埋立地にあっては前述 したとおり，高濃度無機塩類やキレート剂の影響により， 埋立地環境は「高塩類」,「高アルカリ」状態であり, 生 物活性化環境にはない。さらにキレート剂等に起因する 「難分解性有機物」の増加により「準好気性埋立構造」 の位置づけが不明確になってきている。一方で, 降水量 の多いわが国においては, 降水による污濁物の洗い出し による安定化を埋立管理のもう一つの柱としている。こ れらのことから「準好気性埋立」は, 不燃ごみ処分場, 焼却排ガス処理に湿式や乾式ナトリウムを採用している 処分場には, 有機物低負荷対応処分場として有効である と考えらえる。焼却排ガス処理に乾式カルシウムを採用
して, 飛疢処理や溶融飛灰処理に有機系キレート剂を用 いている処分場にあっては, 降水等により塩分低下し, アルカリ状態から中性化した埋立終了後期に有効に機能 すると考えらえる。また埋立ごみ質にかかわらず遮水工 保全のために埋立地内への浸出水の貯留は回避すること が原則であるため,「準好気性埋立」の基本構造は今後 とも必要である。

\section{5 被覆型最終処分場}

近年, 被覆型最終処分場の建設事例が多くなっている。 その背景として, 処分容量の低減化, 被覆による景観向 上，浸出水管理の確実性が高いことなどがあげられる。 一方で, 被覆型最終処分場の多くが浸出水を放流しない 排水クローズド型となっているところが多い。これらは 将来, 処分場閉鎖後, 廃止の際に課題を残している。廃 止の要件の一つである「浸出水が排水基準值等以下にな ること」をどのように達成するのかということと, さら に「腐敗しない廃棄物」の適用を行う場合, その定義が ないため都道府県および政令市は判断に悩むことになる。 近い将来これらの議論を行う必要がある。排水しない施 設の場合は埋立ごみ質の規定が必要になると考えられる。

\section{6 海面処分場について}

海中に直接ごみを投入する海面処分場はわが国特有の 埋立方法である。諸外国にも海面処分場は存在するが, これらは周辺土砂等を浚渫し, 一旦, 陸地を造成したの ちに埋立処分を行う方式である。わが国の海面処分場は ごみの間隙が海水で充填されており, 嫌気的状態となっ ており安定化が極めて遅いのが特徴である。特に有機物 の埋立割合の高い, 古い海面処分場は半永久的に維持管 理しなければならない。対策としては強制通気や酸化剂 注入が考えられる。また比較的新しい焼却残椬主体の海 面処分場については, 前述したキレートの影響が山間埋 立に比べて大きく, 今後の水管理はもちろん, 廃止の際 にも大きな問題になると予想される。処理水の COD 設 定值や飛灰の埋立比率にもよるが筆者らの強制溶出試験 結果によるとキレート剤からの COD 溶出は長期間継続 すると予測される。

\section{7 最終処分場の廃止問題}

最終処分場の廃止基準が定められたのは 1998 年であ る。一般的に最終処分場は 15 年間の埋立期間を設定し て建設されることが多いことから，2013 年頃から埋立 終了時期を迎え, 廃止基準に基づく廃止行為が行われる こととなる。しかし塩素イオン等, 厳しい排水基準の設 定や, 前述した被覆型最終処分場の中には半永久的に廃 
止ができない処分場の存在が予測される。また 1998 年 以前に建設された最終処分場は現行廃止基準の適用がな いため, 仮に埋立終了後 15 年間の維持管理により廃止 されるとすれば，わが国で埋立中もしくは閉鎖後管理中 の最終処分場は 1980 年以降に建設された施設といえる。 この中には依然として埋立地内が高温であったり, メ夕 ンガス等が排出されているものがある。このため後処理 として空気吹き込みや酸化剂注入による早期安定化対策 が必要となる。

\section{8 既設最終処分場の再生と早期安定化}

廃棄物処理システムは社会情勢の変化に応じて変化し てきた。それに伴い廃衰物処理技術も進歩してきた。こ れらに連動して最終処分場に埋立処分される廃棄物の質 も変遷してきた。このため埋立終了後も高濃度の浸出水 やガスが発生し続け安定化が遅れている処分場が存在し, 地域の負の遺産となっている。これらの最終処分場を修 復したり再生することにより負の遺産の解消と最終処分 場の延命化による処分容量不足の解消が可能となる。こ のため,このような事態に対応できる対策技術や早期安 定化技術の開発が望まれている。これらの技術には以下 のようなものがある。

3.8 .1 埋立層内の污濁物質探査技術

早期安定化や埋立再生を行う場合, 埋立層内の分解の 遅れている場所を未然に把握することが必要である。通 常はボーリング等の事前調査を行うが, すべてを把握す ることはできない。特に安定化の遅れた有機物層や埋立 層内宙水位置の探査技術が求められている。

3.8.2 有機物安定化促進技術

1998 (平成 10) 年の基準省令により定められた廃止基 準は, 浸出水水質が排水基準值を 2 年以上にわたって下 回ることやガス発生, 温度, 沈下等について規定され, 諸外国が埋立終了後の経過年数を定めているのに対して 極めて厳しい基準となっている。廃止基準は, 今後, 新 たに建設される最終処分場については廃止基準を想定し た施設造りに活かしていくことができ，たとえば埋立前 処理の導入等により不活性な廃棄物のみを埋め立てるこ とで対処できる。一方, 法規制以前に建設された最終処 分場については, 場合によっては半永久的に廃止できな いことが想定される（たとえば排水基準を自主規制によ り厳しくし，かつ有機污泥等活性廃棄物を埋立処分した 処分場)。このため埋立終了後の維持管理費が嵩み, 民 間の処分場では費用負担できなくなることも考えられる。 このため既設埋立地を早期安定化技術により安定化を促 進させることが考えられる。廃止時期が長期化する要因 として多くの自治体では COD と窒素の低減化が遅いこ
とをあげている。われわれはこれまで埋立層を一種のバ イオリアクターとして捉え, 有機物分解を促進できる準 好気性埋立構造を進めてきた。しかし, 前述した廃止阻 害要因にあげられたCOD に代表されるように，難分解 性有機物の早期分解が求められている。このため筆者ら は好気的方法による易分解性有機物の分解促進とケミカ ルオキシデーションによる難分解性有機物の分解の併用 技術の開発を行っている。

3.8.3 好気的方法によるガス対策と易分解性有機物の 分解

好気的方法による硫化水素やメタンガス対策, および 易分解性有機物の分解方法として空気吹き込み法があげ られる。空気吹き込み法は 3 5 気圧の圧力をかけて間 欠で埋立層内に空気または酸素を吹き込むバイオプース ターと常圧に近い圧力で連続的に空気を吹き达むスメル ウエルおよびその変法がある。

3.8.4 ケミカルオキシデーション法による難分解性有 機物の分解

一般的に埋立地では生物易分解性有機物は早期に分解 されるが, 難分解性有機物は分解に時間を要する。これ らの処理あるいは廃棄物中有機物の分解方式としてケミ カルオキシデーションがある。酸化剂としてはオゾン, 過酸化水素水, 過マンガン酸カリウム等が使用される。 3.8 .5 埋立再生技術

既に建設され埋立終了した処分場や埋立中の処分場に ついては，処分場の廃止まで長期の時間を要し負の遺産 となることが懸念されることから, これらの安定化促進 やリニューアルが求められている。最終処分場は, 焼却 施設等中間処理施設と異なり, 一度満杯に達すると建て 替えができないため，新たな処分場を建設する必要があ る。実際, 一部の市町村では, 既に事態が深刻化してい るところもあり, 既設の処分場の延命化や埋立完了した 用地の再生利用が望まれている。従来, 最終処分場の延 命化のため, 中間処理施設が普及してきた歴史があるが, 既存処分場の中には, 中間処理を受けずに埋立処分され たものも多い。前述した最終処分場の処理処分の変遷か ら, これらの埋立ごみを再処理, 資源化して埋立処分空 間を確保することにより上記問題を解決することができ る。また埋立層を掘削した場合, 当然, 廃棄物が掘り起 こされるが, 現位置で無害化して埋戻材として利用す る場合もある。掘削後トロンメル等で選別し, 必要に 応じて粗大分は破砕, 磁力選別し, 細粒分は洗浄等を行 い, 埋戻材として利用する。燒却残椬主体の埋立地では ダイオキシン類含有量が基準值 (3 ng-TEQ/g) を超え る場合, 現位置で分級後, 加熱還元法等で無害化する場 合もある。 


\section{9 新設最終処分場に求められること}

最終処分場が地域に受け入れられるためには，埋立中， 埋立終了後を通じて地域環境を保全し, 埋立終了後は早 期に安定化および廃止でき, かつ跡地の有効利用ができ るなど負の遺産とならないことが必要である。そのため には遮水工等構造安全な施設はもちろん, 埋立前処理に よる埋立廃棄物の低負荷化および後処理によりバック アップできるシステムが必要である。

\section{9 .1 埋立前処理}

埋立前処理の目的は, 埋立廃棄物の低負荷化と, 埋立 層の通気と通水を確保して微生物活性化と洗い出し効果 促進がある。前者は本来, 焼却等中間処理がそれにあた るが，一般に最終処分場の埋立管理や浸出水管理と整合 していないため, 必要に応じて負荷低減を行う必要があ る（たとえば $\mathrm{pH}$ や塩分濃度が高いと微生物活性化の阻 害要因となる)。後者は污泥のように塑性の大きい廃棄 物は通気や通水に支障を起こし, 宙水の原因となり, 埋 立層内を嫌気的状態にするため改質する必要がある。低 負荷化を目的とした前処理としては「洗浄」がある。 「洗浄」は埋立前に廃棄物を強制洗浄し, 安定化処理し て埋め立てるもので機械洗浄方式や散水洗浄方式等があ る。洗浄排水は膜処理等により処理したのち, 洗浄用水 として循環利用する（洗浄水量は, $1 \sim 10 \mathrm{~m}^{3} /$ ton)。機 械洗浄についてはスパイラル洗浄方式, イジェクター洗 浄方式, エアタービュレンスパイプ方式等がある。洗浄 廃棄物をライシメーターに充填し, 長期挙動をモニタリ ングした結果, 洗浄して埋立処分したほうが安定化が早 いことを確認している ${ }^{12)}$ 。有機污泥等有機物負荷の高い 廃棄物については通気処理による前処理が有効である ${ }^{13)}$ 。 通気，通水確保を目的とした前処理としてはトロンメ ルによる選別や分級処理によるシルト分除去がある。污 泥のように塑性の大きい廃棄物の場合には水分調整剂添 加による改質が効果的である。

3.9 .2 埋立作業

安定化の阻害要因として埋立層内の水みちゃ宙水の存 在がある。一般的に埋立高さと浸出水水質濃度は関連が ある。浸透水の埋立層上層から下層への移動により, 埋 立高さが高くなるほど, 浸出水濃度も高濃度化する。反 面,「水みち」によりショートパスされ，この関連がな い処分場もある。このため埋立作業技術の高度化が求め られる。たとえば, 水みちや宙水の回避のために即日覆 土や中間覆土に空隙のある材料を用いたり, ジオシンセ ティックの活用, 生分解性覆土の使用, あるいは積増埋 立工法等による浸出水濃度抑制等がある ${ }^{14)}$ 。また今後, 埋立層の平均高さと最大高さを制限することも必要であ る。

\subsection{3 埋立後処理}

埋立前処理を行っても, 埋立高さが大きくなると, 通 気や通水に支障をきたし, 安定化が遅れることも考えら れる。そのため必要に応じて後処理を施すことが考えら れる。後処理の方法は 3.8 で述べた, 強制的空気吹き込 み法やケミカルオキシデーション法がある。埋立前ある いは埋立中に埋立終了後に後処理措置がとれるよう配管 等を行っておくことで対処が可能である ${ }^{15)}$ 。

\section{9 .4 浸出水管理}

最近, 梅雨時期のゲリラ的短期集中豪雨により浸出水 の内部貯留を余儀なくされたり，場合によっては未処理 浸出水の越流事故が起きたりしている。一般的には地域 の降水量特性に応じて水収支計算を行うが, 統計デー夕 に基づく降水確率を超過する降水量は予測不可能である。 内部貯留に入ると遮水工に水圧がかかり, 漏水リスクが 高まったり, 埋立層内の嫌気化により, 浸出水濃度等が 上昇し，浸出水管理に支障をきたすことになる。このた め梅雨時等に埋立表面を移動可能なシートでキャッピン グすることや，降水量によっては被覆型処分場も有効な 方策である。

\section{4.おわりに}

わが国のこれまでの廃棄物管理は, 高度経済成長期の 廃棄物量の増加に伴う最終処分場の用地確保難から焼却 等中間処理を廃棄物管理の中心としてきた。一方, 埋立 地においては, 大気污染防止法による塩化水素ガス等の 処理や飛灰の特別管理一般廃棄物指定による安定化処理 が, 埋立管理に与える影響について対症療法的, 事後処 理的対応により実施されてきた。この間，焼却技術の高 度化の結果, 埋立処分にどのような影響があるかは, 殆 ど検討されなかった。現時点で考えると, 排ガスの塩化 水素ガス対策は経済性から石灰等による乾式もしくは半 乾式法が主流となっており, 湿式は一部の大都市の焼却 炉で採用されてきた。このため埋立地では, 浸出水の力 ルシウム除去装置の開発, 脱塩処理技術および濃縮塩処 理技術の開発研究が行われた。しかしカルシウム除去污 泥の増加を含めたコスト検討は行われていないため, 廃 棄物管理全体としての評価は不明のままである。また今 回，有機キレート剂による影響例を紹介したが，無機キ レート剂は殆ど採用されていない。無機キレート剂, 特 にリン系キレート剂の使用例が少ないのは, 排ガス処理 の主流が石灰であり, 酸性のリン系キレート剂を用いる と飛灰中のカルシウムと反応してアパタイトを形成する ためキレート剤添加量が増加し, 結果としてコスト増に なるからと考えられる。しかし埋立管理の面から考える 
と，無機キレート剂を使用することにより，チオ尿素様 物質による硝化阻害や残存キレートによる COD 除去率 低下の問題は回避できることになる。このようなことか ら廃棄物管理として全体のシステムを科学的, 経済的に 見直すことが必要である。

\section{参考文 献}

1）環境産業新聞社：廃棄物年鑑（1985）

2）環境省 廃棄物リサイクル対策室: 一般廃棄物の排出及 び処理状況等 (平成 24 年度) について (2012)

http : //www.env.go.jp/recycle/waste-tech/ippan/h24/ date/env.press.pdf（閲覽日 2014 年 12 月 21 日）

3 ）環境省 廃妄物リサイクル対策室：一般廃妄物の排出及 び処理状況等（平成 22 年度）について（2010）

http : //www.env.go.jp/recycle/waste-tech/ippan/h22/ date/env.press.pdf（閲覧日 2014 年 12 月 21 日）

4) 樋口壯太郎, 武下俊宏：廃棄物処理処分に伴い排出さ れる副生塩のリサイクルシステムの構築に関する研究, 平成 24 年度循環型社会形成推進科学研究費補助金研究 報告書 (2012)

5 ）樋口壯太郎：日本における塩収支と問題点, 廃棄物学 会誌，第 8 巻，第 7 号，pp. 486-492（1997）

6 ）杉本富男, 花嶋正孝, 樋口壯太郎, 横山睦正, 牛越健 一, 吉田 明, 橋本敬行 : 廃棄物処理プロセスより発生 する副生塩再利用の研究, 日本機械学会, 第 18 回環境 工学総合シンポジウム (2008)

7 ）樋口壯太郎：焼却排ガス処理薬剤や飛灰処理キレート が埋立管理に与える影響と対策研究 (3K133007) 平成 25 年度研究報告書, pp. 5-6 (2014)
8 ）久保倉宏一, 富田弘樹, 木村哲久, 吉武和人：キレー 卜処理飛灰溶出液中に残存するジチオカルバミン酸塩 の簡易定量法, 第 29 回全国都市清掃研究・事例発表会 講演論文集，pp. 285-288（2008）

9）林謙次郎, 佐々木義明, 田頭昭二, 柳井富美子：亜硝 酸ナトリウムを用いるチオ尿素の間接吸光光度法, 分 析化学, 第 26 巻, 第 8 号, pp. 511-515(1977)

10）山中建生：独立栄養細菌の生化学, アイピーシー, p. 75 (1999)

11）内田正信, 為田一雄, 樋口壯太郎, 西尾宗馬, 柚田恭 志，石橋修一，楠田哲也：キレート処理飛灰が埋立管 理に与える影響（その 4), 第 34 回全国都市清掃研究 · 事例発表会講演論文集，pp. 205-207（2013）

12）古田秀雄, 松本 真, 樋口壯太郎, 三角文彦, 橋本敬行, 中村寿実, 堀井安雄：廃棄物洗浄型埋立処理 (WOW) システムの実用化のための FS 調査事例，第 16 回廃棄 物学会研究発表会講演論文集, pp. 1105-1107（2005）

13）石田泰之, 樋口壯太郎, 花嶋正孝: 有機污泥埋立にお ける早期安定化技術の研究（第 3 報），第 29 回全国都 市清掃研究・事例発表会講演論文集, pp. 212-214 (2008)

14）矢羽田聡彦, 加藤隆也, 為田一雄, 樋口壯太郎：最終 処分場における塩類抑制制御システム研究 (その 2), 第 33 回全国都市清掃研究·事例発表会講演論文集, pp. 238-240 (2012)

15）宮田剛志, 樋口壯太郎, 花嶋正孝, 為田一雄 : 早期安 定型埋立処分システムの開発に関する研究，第 18 回廃 棄物学会研究発表会講演論文集, pp. 793-795（2007）

16）内田正信：キレート処理飛灰が埋立処理に与える影響 に関する研究, 平成 24 年度修士学位論文, pp. 81-82 (2012)

\title{
Technical Transitions and Future Trends at MSW Landfill Sites
}

\author{
Sotaro Higuchi \\ Graduate School of Engineering, Fukuoka University \\ (1-1 Hibikino, Wakamatsu-ku, Kitakyusyu, Fukuoka 808-0135 Japan)
}

\begin{abstract}
The basic waste disposal process in Japan consists of volume reduction for municipal solid waste, carried out through incineration and crushing, detoxification and landfilling of incineration residues. Incineration residues therefore account for more than $75 \%$ of the wastes destined for landfills. Against such a background, the authors identified challenges associated with landfilling of incineration residues including inorganic salt control, recycling by-product salt, controlling leachate treatment inhibition by organic chelating agents and early stabilization of landfill sites. We also examined methods for solving such challenges.
\end{abstract}

Keywords : quality of landfilled solid waste, inorganic salt, by-product salt, organic chelate agents, nitrification inhibition 